\title{
Changing Face of Plays: A Comparative Research of Childhood Plays of Older Adults and Plays of Today's
}

\author{
Erhan ALABAY*a, Sevcan YAĞAN GÜDER ${ }^{\mathrm{b}}$
}

\begin{tabular}{l} 
Article Info \\
\hline DOI: $10.14686 /$ buefad.325627 \\
\hline Article History: \\
Received $\quad 03.07 .2017$ \\
Revised $\quad 03.01 .2018$ \\
Accepted $\quad 30.01 .2018$ \\
\hline Keywords: \\
Play, \\
Child, \\
Play preferences. \\
\hline Article Type: \\
Research Article \\
\hline
\end{tabular}

\begin{abstract}
The aim of this research is to compare favourite childhood plays of adults aged 60 plus and favourite plays of children between 6 to 10 years old. The research is structured in basic qualitative research methods. Participants of the research, living in İstanbul Province, are composed of 99 adults aged 60 plus and 99 children aged between 6 and 10. In this study, demographic information form and structured interview form for participants were used. Data were analysed through content analysis method. In the wake of findings, while $85.86 \%$ of the adults have stated that when they were children, they loved outdoor plays, it is seen that $36.37 \%$ of today's children love outdoor plays. Additionally, $91.92 \%$ of adults loved group plays, $75.76 \%$ of them loved plays with vehicles and $63.64 \%$ loved plays that require movement whereas $56.57 \%$ of children prefer plays that do not require movement, $49.50 \%$ of them prefer individual plays and $31.32 \%$ prefer plays with vehicles. Besides, it has been detected that $34.34 \%$ of today's children primarily love and prefer plays related with technology.
\end{abstract}

\section{Oyunun Değişen Yüzü: Yetişkinlerin Çocukluk Oyunları İle Günümüz Çocuklarının Oyunlarının Karșılaștırmalı Olarak İncelenmesi}

\begin{tabular}{|c|c|}
\hline \multicolumn{2}{|c|}{ Makale Bilgisi } \\
\hline \multicolumn{2}{|c|}{ DOI: $10.14686 /$ buefad.325627 } \\
\hline $\begin{array}{l}\text { Makale Ge } \\
\text { Geliş } \\
\text { Düzeltme } \\
\text { Kabul }\end{array}$ & $\begin{array}{l}\text { mişi: } \\
03.07 .2017 \\
03.01 .2018 \\
30.01 .2018 \\
\end{array}$ \\
\hline \multicolumn{2}{|c|}{$\begin{array}{l}\text { Anahtar Kelimeler: } \\
\text { Oyun, } \\
\text { Çocuk, } \\
\text { Oyun tercihleri. }\end{array}$} \\
\hline \multicolumn{2}{|c|}{$\begin{array}{l}\text { Makale Türü: } \\
\text { Araştırma Makalesi }\end{array}$} \\
\hline
\end{tabular}

\begin{abstract}
$\ddot{O} \mathbf{z}$
$\mathrm{Bu}$ araştırmanın amacı, 60 yaş ve üzeri yetişkinlerin çocuklukta oynamayı en sevdiği oyunlar ile 6-10 yaş arasındaki çocukların oynamayı en sevdiği oyunların karşılaştırılmasıdır. Araştırma temel nitel araştırma modeli ile tasarlanmıştır. Araştırmanın katılımcılarını, İstanbul ilinde yaşayan 60 yaş ve üzeri 99 yetişkin ve 610 yaş arası 99 çocuk oluşturmaktadır. Çalışmada katılımcılara ait demografik bilgi formu ve yarı yapılandırılmış görüşme formu kullanılmıştır. Ham veriler içerik analizi ile analiz edilmiştir. Bulgular sonucunda, yetişkinlerin \% $\% 5,86$ 's ç çocukken diş alanda oynanan oyunları sevdiklerini belirtirken, günümüz çocuklarının ise $\% 36,37$ 'sinin dış alanda oynanan oyunları sevdiği sonucuna ulaşılmıştır. Ayrıca yetişkinlerin \%91,92'si grup oyunlarını, \%75,76'sının araçlı oyunları ve \%63,64'ünün ise hareketli oyunları sevdiklerini belirtirken; çocukların \%56,57'sinin hareket gerektirmeyen oyunları, $\% 49,50$ 'sinin bireysel oyunları ve \%31,32'sinin araçlı oyunları tercih ettiği sonucuna ulaşılmıştır. Ayrıca günümüz çocuklarının \%34,34'ünün en çok teknoloji ile ilgili oyunları sevdiği ve tercih ettiği tespit edilmiştir.
\end{abstract} oyunlari sevdiğ

\footnotetext{
*Corresponding Author: erhanalabay@aydin.edu.tr

a Asst. Prof. Dr., İstanbul Aydın University, Faculty of Health Sciences, Child Development Department, İstanbul/TURKEY, https://orcid.org/0000-0003-4025-2352

${ }^{b}$ Asst. Prof. Dr., İstanbul Kültür University, Faculty of Education, Preschool Education Department, İstanbul/TURKEY, https://orcid.org/0000-0002-6423-3693
} 


\section{Introduction}

Each child, as of his birth, wonders about the real world and begins exploring and discovering his social environment. In accordance with this effort of exploration and discovery, one of the most frequently used methods is play. Children recognise and make sense of the objects around them thanks to their plays; further, they reflect their thoughts and feelings through plays (Hirsh-Pasek, Golinkoff, Berk and Singer, 2009; Jones and Cooper, 2006). According to Piaget (1962), there is no need for spoken language in plays. Children convey their feelings by means of their body language during plays without needing for spoken language. However, Vygostky (1967), while describing the play as a social activity, specified that children utilize plays not only as an instrument of entertainment, they also prefer them as a means to fulfil their needs (As cited in. Metin-Aslan, 2013). For that reason, it is generally possible to describe play as an indispensable pastime of children.

Play is a learning environment which supports all developmental stages of a child. By means of play, the child's psychomotor, language, cognitive, social-emotional skills and self-care abilities are promoted. In the experimental research of Kuru and Köksalan (2012) in which they examined the effects of plays over children's basic motor skills and their developments, it has been concluded that plays which lasted for 14 weeks enhanced children's motor skills such as running, throwing and catching the ball, leaping forward and upward. In the study where play and exercise program developed by Kerkez (2006) was examined in terms of its effects over children's physical and motor development levels, it has been found out that the play and exercise program is efficient in normalising physical and motor capabilities of disadvantageous children who are affected by negative environmental conditions. And in the study of Gözalan and Koçak (2014) which examines the effects of play over language development, it has been detected that the play-based attention training program has an effective role in enhancing vocabulary of 60 to 72-month-old children. In the research in which Türkoğlu and Uslu (2016) examined the effects of play-based cognitive development program over cognitive development of 60 to 72 -month-old children, it has been revealed in the wake of the program carried out for 12 weeks that there has been a significant increase in cognitive development points of experimental group children who practised the program and the effects are permanent. Additionally, Kaya (2010) has applied play intervention program to the children with special needs and it has been found out as a result of the program that cognitive skills points of experimental group children with special needs are significantly higher compared to those of the control group children. In the same research, it has also been detected that performances of experimental group children with special needs differed positively before and after intervention. There are studies, as well, on the fact that play affects social and emotional development of children. For instance; it has been determined that play-based social skills training which was developed by Durualp and Aral (2010) and applied for eight weeks has significantly increased children's points of social skills. Thereby, it is seen that play contribute to holistic development of children.

However, it has been frequently observed nowadays that children, rather than interactive plays with their peers, play console games on the virtual ground of computer and smart phones within technology, pc games and online games. As a result of the research conducted by Akçay and Özcebe (2012) with the purpose of assessing preschool children and their families' habits of playing computer games, it has been detected that $44.1 \%$ of preschool children play computer games. And in the descriptive study Gündoğdu et al. (2016) carried out regarding media usage of preschool children, it has been reported that each child constituting the sample of the research spend one or more hours during the day with one or more technological device. It has been particularly concluded that the period of time when children deal with a technological device is mostly mealtime. Besides, upon examining children's traditional plays in the past, it has been observed that children generally used to play with their peers whereas children of today play individually in general. In the study where Kocyigit and Baydilek-Başara (2015) examined preschool children's perceptions of play, they reported that children usually play alone at home. As a result of the study conducted by Toran and Dilek (2017), it has been seen that plays are not included in the books of children, as well. It has been detected that out of 200 illustrated story books, only 18 of them include plays. Başal (2007) stated that plays, which are extremely important in the life of a child, have changed with the influence of technology. Similar results have been obtained as a consequence of a research carried out in England. It has been seen that $26 \%$ of children between 12 and 15 years old and $18 \%$ of children between 8 and 11 years old have their own tablet computers; and the rate of tablet computer possession in the households has increased from $20 \%$ to $50 \%$ (Given et al., 2015). While new toys are being introduced with the advance of technology, traditional plays and toys, on the other hand, are falling into oblivion. 
The aim of this research is to compare characteristics of the plays that adults, aged 60 plus primarily, loved playing when they were 6 to 10 years old and the plays today's children between 6 to 10 years old love playing. In accordance with main purpose, answers for the following research questions have been sought:

a. What are the characteristics of the plays that adults play when they were 6 to 10 years old? (The environment of the play, the way it is played, usage of vehicles, play group, etc.)

b. What are the characteristics of the plays that today's children aged between 6 and 10 primarily love? (The environment of the play, the way it is played, usage of vehicles, play group, etc.)

c. What kind of similarities and differences are there in the characteristics of plays of adults and the plays of today's children?

The main headings should be in Times New Roman, 11pt. The text should be in Times New Roman, 10pt, single line spacing and justified on both sides. The main topic of the research, brief information about the sections of the study, its place in the literature, the significance of the study, research problem(s) and purpose(s) should be included in this part. If needed, subheadings can be used in this section.

\section{Method}

\section{Research Design}

This research has been structured in 'Basic Qualitative Research'. Basic Qualitative Researches are studies which ensure to reveal a situation or incident in their natural environment in a holistic and realistic way. Data in basic qualitative researches is collected through qualitative data collection methods such as interview, observation and document analysis (Karataş, 2015). In order to determine favourite plays of adults and children and compare them, semi-structured interview technique has been used by utilizing semi-structured interview forms.

\section{Participants}

Among purposeful sampling methods, criterion sampling has been used in this research. In criterion sampling method, a series of criteria are prepared by the researcher in accordance with the purpose of the research Yildirım and Şimşek, 2005). Age scale has been used as a criterion in this research. In determining children's favourite plays, children between the ages of 6 and 10, and determining favourite childhood plays of adults, people aged 60 and above have been designated as a criterion. Additionally, from the family of each adult aged 60 and above, within sampling group, a child between the ages of 6 and 10 has been included in the research. This practice which has been implemented in order to eliminate the differences resulting from family structure has constituted a criterion in the specification of the participants.

In order to ensure the plays and characteristics of the plays within the research to encompass regional and cultural differences, İstanbul Mobility Report (2016) was used as a base. In line with İstanbul Mobility Report (2016), since Maltepe district is the county which has received the highest number of immigrants in the Anatolian Side of İstanbul, the research has been conducted in Maltepe district, İstanbul province. Within the body of Ministry of National Education, 3 independent preschool and 3 primary schools with high-medium and low socioeconomic levels have been designated in Maltepe district. From the designated schools, 99 children between the ages of 6 and 10 and 99 adults aged 60 and above from the families of the same children, 198 people in total, have been included in the research. Demographic information of the participants included in the research is presented on Table 1. 
Table 1. Demographic Information of the Participants

\begin{tabular}{|c|c|c|c|c|c|c|c|}
\hline \multicolumn{4}{|c|}{ Information on Adults } & \multicolumn{4}{|c|}{ Information on Children } \\
\hline & & $\mathbf{n}$ & $\%$ & & & $\mathbf{n}$ & $\%$ \\
\hline \multirow{3}{*}{ Gender } & Man & 52 & 52,53 & \multirow{3}{*}{ Gender } & Boy & 51 & 51,52 \\
\hline & Woman & 47 & 47,47 & & Girl & 48 & 48,48 \\
\hline & Total & 99 & 100 & & Total & 99 & 100 \\
\hline \multirow{6}{*}{$\begin{array}{l}\text { Educational } \\
\text { Background }\end{array}$} & Unschooled & 20 & 20,20 & \multirow{3}{*}{$\begin{array}{c}\text { State of } \\
\text { Education }\end{array}$} & Preschool & 22 & 22,22 \\
\hline & Primary School & 54 & 54,55 & & Primary School & 77 & 77,78 \\
\hline & Secondary School & 8 & 8,08 & & Total & 99 & 100 \\
\hline & High School & 11 & 11,11 & & & & \\
\hline & University & 6 & 6,06 & & & & \\
\hline & Total & 99 & 100 & & & & \\
\hline
\end{tabular}

On examining Table 1; it is detected that $52.53 \%$ of the adults participating in the research are men, $47.47 \%$ of them are women, $54.55 \%$ of them are primary school graduates, $11.11 \%$ of them are graduates of high school, $8.08 \%$ of them are graduates of secondary school and $6.06 \%$ of them are graduated from university whereas $20.20 \%$ of the participants have received no education. Upon examining the percentages of children who constitute the other division of the research, it is seen that $51.52 \%$ of the children participating in the research are boys, $48.48 \%$ of them are girls and $77.78 \%$ of them are attending primary school and $22.22 \%$ of them are in preschool. Furthermore, it is detected that age average of the adults participating in the research is 68.1 and children's age average is 7.98.In accordance with the content of the study, please choose one of the above (Population and Sample / Study Group / Participants). Quantitative research should include explicit information about the population and sampling methods. In qualitative research, study groups should be used included rather than sampling since the study group method is conducted by the participation of multiple individuals or units. The individuals or the units constituting the target group should be introduced. The information related to the context of the target group should be stated here.

\section{Data Collection Tools}

So as to specify favourite plays of adults and children, 'Interview Forms for Determining Plays' prepared both for adults and children separately have been used in the research. While interview forms prepared for adults include such demographic information as gender, age, educational background, in the form prepared for children, demographic information questions on children's age and the level of schools they are attending are included. In Children's Interview Form for Determining Plays, there are two open-ended questions in order to determine favourite plays of children. These questions are; 'What is your favourite play?' and 'Could you tell us about this play?'. In Adults' Interview Form for Determining Plays, questions are 'What was your favourite play when you were between 6 to 10 years old?' and 'Could you tell us about this play?'

Before beginning to data collection process, 'Adults' and Children's Interview Forms for Determining Plays', so as to be expertised, have been presented to 2 academic members who are the authority in the field of education and plays. In accordance with the expert opinions, the forms have taken their final shape. Additionally, a pilot prestudy in compliance with the characteristics of research group has been carried out. The pilot pre-study, which aimed to find out whether or not semantic and structural clarity are ensured, has been carried out with 5 children between 6 and 10 years old and 5 adults aged 60 and above.

\section{Data Collection}

The research was carried out between November, 2015 and February 2016. Within the context of the research, face to face interviews have been performed with 60 and above-year-old adults and 6 to 10-year-old children who are living in Maltepe district. Interviews with children have been carried out in their own schools, yet in another place apart from their classrooms so as not to cause them to be influenced by anyone else. Before the interviews to be done with children's parents aged 60 and above, it was made an appointment through telephone. Specifying the date and hour of the appointment, individual interviews have been carried out with the adults in children's schools. Averagely 5 minutes of interview has been performed with each participant. The researcher has directed the questions in semi-structured interview form to the participant during the interviews. And the answers given by the participants have been noted down on the spaces previously designated on the interview form. If the plays 
stated by children and adults are not known by the researcher, the characteristics of the plays have been revealed through asking probe questions.

\section{Data Analysis}

The answers given by the adults and children included in the research have been analyzed through content analysis technique. With the purpose of revealing common properties of numerous text contents, content analysis is a technique which enables generalization from qualitative to quantitative towards structuring significant contents (Gökçe, 2006).

With the intention of keeping the confidentiality of adults and children participating in the research, codification system has been utilized. Adults have been coded with ' $A$ ' and children with ' $C$ '. And the number available next to the code is the order number given to the form during the interview.

In an attempt to ensure data credibility in the research, 'inter-coder agreement' principle has been employed. During the process of data analysis, answers given by adults and children have been evaluated independently by two researchers and categories are formed with the codes arisen. Following this, researchers, leaguing together, have figured inter-observer consistency. Inter-observer consistency is obtained through dividing the number of consistent items by total number of the items and multiplying the result with 100 (Creswell, 2013). Inter-observer consistency in the research has been calculated to be $93.11 \%$.

\section{Findings}

The plays stated by adults and children and analysed as part of the research have been examined in terms of the environment the play is performed (outdoors, indoors), the way it is played (active plays, stationary plays), using instruments within the play ( the plays with instruments, the plays with technological instruments and the plays without instruments), the play group (individual plays, group plays), creativity (structured instruments, unstructured instruments, the plays without instruments), availability of tagging ( the plays with tagging, the plays without tagging) and availability of tongue twisters (the plays with tongue twisters, the plays without tongue twisters).

\section{What are the characteristics of the plays that adults play when they were 6 to 10 years old?}

The questions; 'What was your favourite play when you were between 6 to 10 years old?' and 'Could you tell us about this play?', which were asked as part of the research to the adults aged 60 and above, have been analysed. Content analysis results of the answers given by the adults are presented on Table 2.

Table 2. The Characteristics of the Favourite Play Adults Aged 60 and Above Loved Playing When They Were Between 6 and 10 Years Old.

\begin{tabular}{llrr} 
& & $\mathbf{n}$ & $\mathbf{\%}$ \\
\hline The environment the play is performed & Outdoors & 85 & 85,86 \\
& Indoors & 14 & 14,14 \\
& Total & 99 & 100 \\
\hline The way it is played & Active Play & 63 & 63,64 \\
& Stationary Play & 36 & 36,36 \\
& Total & 99 & 100 \\
\hline Using instruments within the play & Plays with instruments & 75 & 75,76 \\
& Technological instruments & - & - \\
& Plays without instruments & 24 & 24,24 \\
& Total & 99 & 100 \\
\hline Structuring the instruments used & Structured Instruments & 11 & 11,11 \\
& Unstructured Instruments & 64 & 64,65 \\
& Without instruments & 24 & 24,24 \\
& Total & 99 & 100 \\
\hline Play group & Individual Plays & 8 & 8,08 \\
\hline
\end{tabular}




\begin{tabular}{llrr}
\hline & Group Plays & 91 & 91,92 \\
& Total & 99 & 100 \\
\hline Availability of tagging & Plays with Tagging & 34 & 34,34 \\
& Plays without Tagging & 65 & 65,66 \\
& Total & 99 & 100 \\
\hline Availability of tongue twisters & Plays with tongue twisters & 19 & 19,19 \\
& Plays without tongue twisters & 80 & 80,81 \\
& Total & 99 & 100 \\
\hline
\end{tabular}

Upon examining Table 2, it has been concluded that $85.86 \%$ of the plays adults aged 60 and above loved playing when they were between 6 and 10 years old are outdoor plays, $14.14 \%$ of them are indoor plays. It is detected that $63.64 \%$ of the plays of adults were active plays while $36.36 \%$ of them were stationary plays. Furthermore, it is seen that instruments were used in $75.76 \%$ of the plays and $11.11 \%$ of those instruments were structured while $64.65 \%$ of them were unstructured instruments. When the table is examined based on play groups, it is understood that $91.92 \%$ of the plays were played in a group and $8.08 \%$ of them were played individually. In terms of availability of tagging within the plays, tagging was available in $65.66 \%$ of the plays while it was not available in $34.34 \%$ of the plays. It is seen that whereas tongue twisters were not available in $80.81 \%$ of the plays, they were available in $19.19 \%$ of the plays.

A71- "My favourite play was leapfrogging. We used to play it with 5 or more friends. We used to select a friend as 'pillow' before we began playing. This friend used to lean against the wall. Three friends used to bend over and form a row putting their head between legs of each other beginning with the 'pillow'. The fifth friend used to come running from a distance and jump over the row to reach on the first friend." (Age 77, Man)

A22- "My favourite play was forming a cow out of earthenware water jug. We used to break earthenware water jug into pieces and give the pieces the shape of a cow. When we put water in it, it used to look as if we are milking the cow. " (Age 78, Woman)

A90- "I used to like 'my hand, my hand a butterfly' play a lot. We used to sit and form a circle with our friends and everybody used to open their hands place them on the ground. There used to be a tagged person and she or he used to start counting the fingers on the ground. While counting, she used to say the tongue twister 'My hand, my hand a butterfly/ Came from a tree nearby / Baa Baa says the black sheep/ Before it falls asleep/ Take this out, leave it out' Whoever's finger she was on when the tongue twister ended, that person used to bend that finger into her palm. Then the play continues in this way and those whose all fingers are bent used to be eliminated. And the last person remained would be the winner." (Age 80, Woman)

A10- "The play of ankle bone on the ice. We used to collect ankle bones of sheep. Approximately 20-25 pieces. We used to draw a circle on the ice, line up all the ankle bones within that circle. Then, we would get 10 steps away from the circle. Five friends, in turns, would try to strike the ankle bones on the circle with the one they had in their hands. Whoever hits the highest number of ankle bones used to win." (Age 73, Men)

\section{What are the characteristics of the plays that today's children aged between 6 and 10 primarily love?}

The questions; 'What is your favourite play?' and 'Could you tell us about this play?', which were asked to the children aged 6 to 10 as part of Children's Interview Forms for Determining Plays, have been analysed. Content analysis results of the answers given by the children are presented on Table 3 . 
Table 3. Characteristics of the Favourite Play Children Aged 6 to 10 Love Playing

\begin{tabular}{llrr} 
& & $\mathbf{n}$ & $\mathbf{\%}$ \\
\hline The environment the play is performed & Outdoors & 36 & 36,37 \\
& Indoors & 63 & 63,63 \\
& Total & 99 & 100 \\
\hline The way it is played & Active Play & 43 & 43,43 \\
& Stationary Play & 56 & 56,57 \\
& Total & 99 & 100 \\
\hline Using instruments within the play & Plays with instruments & 31 & 31,32 \\
& Technological instruments & 34 & 34,34 \\
& Plays without instruments & 34 & 34,34 \\
& Total & 99 & 100 \\
\hline Structuring the instruments used & Structured Instruments & 60 & 60,61 \\
& Unstructured Instruments & 5 & 5,05 \\
& Without instruments & 34 & 34,34 \\
& Total & 99 & 100 \\
\hline Play group & Individual Plays & 49 & 49,49 \\
& Group Plays & 50 & 50,51 \\
& Total & 99 & 100 \\
\hline Availability of tagging & Plays with Tagging & 32 & 32,32 \\
& Plays without Tagging & 67 & 67,68 \\
& Total & 99 & 100 \\
\hline Availability of tongue twisters & Plays with tongue twisters & 11 & 11,11 \\
& Plays without tongue twisters & 88 & 88,89 \\
& Total & 99 & 100 \\
\hline
\end{tabular}

Upon examining Table 3, it has been concluded that based on the environment of the favourite plays of today's children, $63.63 \%$ of them are played indoors and $36.37 \%$ of them are played outdoors; based on the way it is played, $56.57 \%$ of them are stationary plays and $43.43 \%$ of them are active plays; based on play group, $50.51 \%$ of them are played in a group and $49.49 \%$ of them are played individually; based on the availability of tagging, $67.68 \%$ of the play do not include tagging and $32.32 \%$ of them include tagging; and based on the availability of tongue twisters, there aren't tongue twisters in $88.89 \%$ of the plays while there are tongue twisters in $11.11 \%$ of them. On examining usage of instruments in the plays stated by children, It has been detected that instruments are used in $65.66 \%$ of the plays and $34.34 \%$ of the instruments used are technological instruments.

C44. "My favourite game Winx. can be played through tablet computer. After choosing a character and dressing her initially, you create the others. But you need to earn money so as to complete the levels and if the person you created doesn't like it, you start it over." (Age 7, Girl)

C69. "My favourite game is Subway Surf. You run away from the police without crashing the trains. Then you collect gold coins. You can buy characters or items by saving gold coins. After that you collect boxes and receive gifts. Through the boxes you can have skateboards, money, hats and ability of flying." (Age 6, Boy)

C9. "I love the play of Police. It is played in a group. Half of the group are policemen and the other half are thieves. Policemen have their guns in their hands; they catch the thieves and kill them. The one who kills the highest number of thieves are awarded at the end of the play." (Age 9, Boy). Girl)

C56. " My favourite play is dressing my Barbie doll and going out to park with her." (Age 6,

C91. " My favourite play is 'the telephone' Children line up in a row. The child at the beginning of the row is told a word. He tells the word to the child next to him. And that one to the other child next to him. The child at the end of the row tries to tell the correct word." (Age 6, Girl) 
C99. "the play of Doctor. The play is performed with 10 children. One of the children is selected, the one who is selected becomes the doctor, the others sit down. Doctor stands up. Doctor thinks of a number up to 10. Then he asks everyone to tell a number. The child who knows the number doctor thought goes near him. They both think of a number each, and ask to the 8 children remaining. The play goes on until there is only one child left." (Age 10, Boy)

What kind of similarities and differences are there in the characteristics of plays of adults and the plays of today's children?

The characteristics of the favourite plays of adults aged 60 and above loved playing when they were between 6 and 10 years old and the favourite plays of the children love playing today are comparatively presented in Table 4.

Table 4. Comparison of the Characteristics of the Plays Adults and Children Love Playing

\begin{tabular}{llrrrr} 
& & \multicolumn{2}{c}{ Adult } & \multicolumn{2}{c}{ Child } \\
\cline { 3 - 5 } The environment the play is performed & & $\mathbf{n}$ & $\%$ & $\mathbf{n}$ & $\%$ \\
& Outdoors & 85 & 85,86 & 36 & 36,37 \\
& Indoors & 14 & 14,14 & 63 & 63,63 \\
& Total & 99 & 100 & 99 & 100 \\
\hline The way it is played & Active Play & 63 & 63,64 & 43 & 43,43 \\
& Stationary Play & 36 & 36,36 & 56 & 56,57 \\
& Total & 99 & 100 & 99 & 100 \\
\hline Using instruments within the play & Plays with instruments & 75 & 75,76 & 31 & 31,32 \\
& Technological instruments & - & - & 34 & 34,34 \\
& Plays without instruments & 24 & 24,24 & 34 & 34,34 \\
& Total & 99 & 100 & 99 & 100 \\
\hline Structuring the instruments used & Structured Instruments & 11 & 11,11 & 60 & 60,61 \\
& Unstructured Instruments & 64 & 64,65 & 5 & 5,05 \\
& Without instruments & 24 & 24,24 & 34 & 34,34 \\
& Total & 99 & 100 & 99 & 100 \\
\hline Play group & Individual Plays & 8 & 8,08 & 49 & 49,49 \\
& Group Plays & 91 & 91,92 & 50 & 50,51 \\
& Total & 99 & 100 & 99 & 100 \\
\hline Availability of tagging & Plays with Tagging & 34 & 34,34 & 32 & 32,32 \\
& Plays without Tagging & 65 & 65,66 & 67 & 67,68 \\
& Total & 99 & 100 & 99 & 100 \\
\hline Availability of tongue twisters & Plays with tongue twisters & 19 & 19,19 & 11 & 11,11 \\
& Plays without tongue twisters & 80 & 80,81 & 88 & 88,89 \\
& Total & 99 & 100 & 99 & 100 \\
\hline
\end{tabular}

On examining Table 4, it has been concluded that considering the plays adults, included in the study group, loved playing when they were children; $85.86 \%$ of them are played outdoors, $14.14 \%$ of them are played indoors. On the other hand, only $36.37 \%$ of the plays of today's children are played outdoors whereas $63.63 \%$ of them are played indoors. In another words, it has been determined that adults state that they performed their favourite plays mostly outdoors when they were children while most of the favourite plays of today's children are played indoors. It is established that more than half of the favourite plays of adults are active plays (\%63.64). However, it has been concluded that more than half of the favourite plays of children in the study group are stationary plays (\%56.57).

One of the biggest differences between the characteristics of the plays of adults loved playing when they were children and the plays of today's children is the selection of the instrument used in the play. It is detected that $34.34 \%$ of the favourite plays of today's children are performed through technological instruments. It has been concluded that in $75.76 \%$ of childhood plays of adults, instruments were used and none of those instruments were 
technological. Besides, upon examining the instruments adult used in their childhood plays, it is seen that $64.65 \%$ of them are unstructured instruments. In other words, while adults could use a piece of wood, a stone, a piece of bone or a crown cap as an instrument in their childhood plays, majority of today's children use instruments created within a purpose.

As a result of the interviews carried out with adults, it has been understood that whereas nearly all the plays they stated are played in a group (91.92\%), only $50.51 \%$ of the favourite plays of today's children are played in a group. In other words, it is detected that nearly half of the favourite plays of today's children are played individually. Likewise, upon examining the availability of tagging and tongue twisters within the plays, similar percentages are seen to exist between the characteristics of the favourite childhood plays of adults and the favourite plays of today's children. While tagging is available in $34.34 \%$ of the plays stated by adults, tagging is detected to be available in $32.32 \%$ of the plays of children. Based on the availability of tongue twisters, it is seen that tongue twisters were available in $19.19 \%$ of adult's plays and in $11.11 \%$ of the plays of children.

\section{Discussion and Conclusion}

In this research conducted with the purpose of examining the similarities and differences between the characteristics of the favourite plays of adults aged 60 and above loved playing when they were between 6 and 10 years old and the characteristics of the favourite plays of the children between 6 and 10 years old love playing today, one of the results obtained is that the environment the plays are performed has differentiated. It has been concluded at the end of the research that most of the favourite childhood plays of adults were played outdoors; yet, more than half of the plays of today's children are played indoors. In Fleer's research (2014) conducted with teachers and in Clement's research (2004) conducted with mothers, both teachers and mothers stated that they played outdoors more in their childhood years compared to today's children.

It can be assumed that the reason why today's children play outdoors less may be owing to the parents' concerns over outdoors. In their study carried out with the aim of determining the opportunities of playing outdoors for children who attend preschool institutions in Denizli province and the parents' opinions over this issue, CevherKalburan (2014) concluded that parents have concerns about children's playing outdoors. Parents have stated their concerns particularly over the possibility of incidents such as traffic, ill-intentioned strangers, kidnapping and injuries. Similar results have also been reported in Veitch, Bagley, Ball and Salmon's research, which was carried out to specify the perceptions of parents with low, medium and high socio-economic levels in Australia over where their children play and why. In line with the opinions of 78 parents participating in the research, it is concluded that $94 \%$ of the parents are concerned about the security of playgrounds. They expressed the reasons of their concerns as foreigners, teenagers and proximity to vehicle traffic.

In the research of Deretarla-Gül (2012), in which materials in the playgrounds and the specifications of the playgrounds are assessed by parents, among the reasons of why parents prefer going playgrounds with their children, playgounds' being located in a safe environment has been the second reason with 36.6\%. Also in the study conducted by Fleer (2014), teachers are asked their opinions about their childhood plays. Teachers stated that their parents didn't feel much concern while they were playing, yet; parents today feel much more concern. Clements (2004), in his research, has suggested the fact that children of today play outdoors less compared to the children of previous generation is owing to addiction to TV and digital media, and concerns over security and crime.

Another reason for today's children's performing more than half of their plays indoors may be considered to be because of the fact that outdoor playing activities are not sufficiently included in formal education programs. As a result of the study of Alat, Akgümüş and Cavalı (2012), carried out so as to reveal the attitudes, opinions and practices of preschool teachers on outdoor activities, it has been detected that teachers have positive attitude and opinions towards outdoor activities. However, with regard to the practices of outdoor activities, it is concluded that they are not performed due to such reasons as insufficiency of physical conditions, inadequacy of safety measures in school gardens, teachers' concerns over children's possibility of getting ill due to weather conditions and negative reactions from parents. Preschools institutions in Kocaeli have been analysed by Çelik (2012) in terms of quality of their playgrounds and 9 preschool institutions in total have been examined. In the wake of the study, it is reported that outdoor areas within the body of preschool institutions are not utilized effectively, 
available outdoor areas are not appropriate for the plays of children and there are deficiencies in terms of physical arrangements.

Another reason for the outcome that more than half of the plays of children are performed indoors may be the point of view towards preschool training and expectations from preschool training. Fleer $(2013 ; 2010)$ determined that families are more satisfied with academic-oriented activities in preschool training. Hence, it can be presumed that teachers have to focus mostly on academic activities in preschool training and this is influential in reducing playing habits of children. Miller and Almon (2009) reported that in many preschool institutions in the USA, children spend more time on literacy and mathematics rather than learning through plays and discovery and use their bodies and imaginations; and thus many children are obliged to struggle to comply with the academic standards which are inappropriate in terms of development. The same situation is valid in our country, as well. Based on Tedmem's report published in 2016 with the title of 'Have Preschool Institutions Turned into Primary School First Grade?', preschool are increasingly diverging from play-oriented practices and they gradually focus on academic skills. In his article, Nicolopoulou (2010) stated that preschools are moving away from play day by day.

On the other hand, not planning play-oriented activities and causing children be stationary for a long time may affect children's behaviours of play. In their study Dale et al. (2000) stated that children who sit still for a long time in the school tend not to move at home, as well. Getting used to this immobility has been detected as a strong factor in detaining children from playing outdoors and urging them to play with technological devices and to watch them TV. This view is also supported by the finding, another result of the research, that more than half of the childhood plays of adults were active plays while more than half of the plays of today's children are stationary plays. Clement (2004) stated that compared to the previous generation, children in the USA perform plays which require less activity. The reason of this situation can be associated with children's inactive lifestyles. As a result of the study of Kudaş, Ülkar, Erdoğan ve Çırçı (2005), where they examined the physical activities and dietary habits of 11 and 12-year-old children living in Ankara province, it has been detected that there is a remarkable amount of decrease in the physical activity levels of children particularly during school hours. Based on the results of Turkish Nutrition and Health Survey (2010), it has been concluded that 58.4\% of children between the ages of 6 and 11 in Turkey do not do exercise for 30 or more minutes a day, a regular exercise in other words. The rate of those who don't do exercise is detected to be $65.8 \%$ in 6-8 age group and 52.7\% in 9-11 age group. Bodrova and Leong, (2003) and Pica (2003), in their studies, drew attention to the fact that children are more inactive compared to the previous generation and they highlighted increasing childhood obesity.

Another reason for the fact that more than half of the plays of today's children are performed indoors may be the scarcity of playground to play outdoors. In a research conducted by Şener (2001), usability of playgrounds and school gardens are examined. A survey study has been carried out in three districts in İstanbul with different income status; and as a consequence of the survey, it has been concluded that children need playgrounds and school gardens are not utilised out of school hours. Gönen and Saranlı (2014) have conducted a research so as to examine the sufficiency of indoor and outdoor activity areas of preschool institutions. Upon examining the results of the research, it has been concluded that almost in all preschool institutions included in the sampling own an area allocated for the activity of children, yet this areas are not efficiently structured. Additionally, it has been seen that ground material of the areas are not convenient for healthy movements of children. In Koçan's (2012) study conducted over the adequacy of children's playgrounds, while 10 square metres of playground and green area should be allocated per child, it is seen that 2 square metres of playground is available per child considering the present size.

Another result obtained from the research is that while nearly all of the adult plays are group plays (91.92\%), only $51.51 \%$ of the favourite plays of today's children are group plays. In another word, nearly half of today's children love individual plays more. This may result from various factors. First of the reason is that nuclear families are more common and accordingly children play in a group only if they have brothers or sisters. On the other hand, being the only child in the family can be a factor. In a research carried out by Taylı (2007), upon examining social play preferences of single child and children with siblings, it is determined that children with siblings prefer shared and cooperative plays more than a single child. In other words, single children prefer individual play more frequently. Additionally, such factors as the lack of neighbourhood culture as in the past, oblivion of good neighbourhood relations and unawareness of the neighbouring children at the same age from the existence of each other can be a significant factor in children's preferring individual plays. 
Increase in the level of technology usage, substitution of such devices as televisions, tablet computers and mobile phones for their friends can be seen as a factor in children's preferring individual plays instead of group plays. In a research carried out by Akçay and Özcebe (2012), it is reported that the habits of playing computer games are available even in preschool age group and the duration of playing games, particularly at the ages between 4 and 6, is too long for this age group. Likewise, in the researches of Gündoğdu et al. (2016), it has been reported that each child constituting the sample of the research spend one or more hours during the day with one or more technological device. In the study of Erbay and Durmuşoğlu (2012), where they examined the role of play in the routine activities of children during their daily lives, it has been concluded that nearly all of the children played games most of the time and majority of them watched TV, along with their performing artistic activities, helping daily chorus, spending time with computer and going for a walk. In the study, the concern over the substitution of watching TV for playing has specifically been expressed.

Based upon the data of the research, parents can be informed that children should be encouraged to play social games with their peers, parents should attach importance to playing outdoors and create opportunities for this and restrict their children's time period spent over technological games. Within this context, it is of a great importance that parents teach their childhood plays to their children, create opportunities for playing with them and supports them. They should prepare plays that can be performed as a family and thus promote their children's acquiring social skills by enhancing domestic communication. Parents with their children can make toys out of surplus materials and create plays using these toys.

On the other hand, importance of play-oriented activities in preschool institutions should not be forgotten. Accordingly, significant missions are waiting for teachers. It is crucial that teachers structure their activities playoriented, encourage their students in playmaking and support them in planning their plays. Teachers should raise awareness in the families about play and the importance of them for children, inform the parents about training objectives of preschool education, promote families so as to set up an environment to play with their children and recommend them the plays they can perform together. 


\section{Oyunun Değişen Yüzü: Yetişkinlerin Çocukluk Oyunları İle Günümüz Çocuklarının Oyunlarının Karşılaştırmalı Olarak İncelenmesi}

\section{Giriş}

Her çocuk, doğumuyla birlikte gerçek dünyayı merak eder ve sosyal çevresini keşfetmeye ve araştırmaya başlar. Bu keşfetme ve araştırma çabası doğrultusunda en sık kullandığı yöntemlerden birisi de oyundur. Çocuklar oyunları sayesinde çevresindeki nesneleri tanır, anlamlandırır hatta duygu ve düşüncelerini oyun yoluyla dışa aktarır (Hirsh-Pasek, Golinkoff, Berk ve Singer, 2009; Jones ve Cooper, 2006). Piaget'e (1962) göre oyunda konuşma dili olmasına gerek yoktur. Çocuklar oyunlarında konuşma diline gerek duymadan da duygularını beden dillerini kullanarak aktarırlar. Vygostky (1967) ise oyunu toplumsal bir etkinlik olarak tanımlarken, çocukların oyunu sadece zevk veren bir eğlence aracı olarak kullanmadı̆̆ını, aynı zamanda ihtiyaçlarını gidermek için bir yol olarak seçtiklerini de belirtmiştir (Akt. Metin-Aslan, 2013). Bu nedenle genel olarak oyunu çocuğun vazgeçilmez bir uğraşısı olarak tanımlamak mümkündür.

Oyun, çocuğun tüm gelişim aşamalarını destekleyen bir öğrenme ortamıdır. Oyun sayesinde çocuğun psikomotor, dil, bilişsel, sosyal-duygusal gelişimleri ve özbakım becerileri desteklenir. Kuru ve Köksalan'ın (2012) oyunların çocukların temel motor becerilerine ve gelişimlerine etkisini araştırdıkları deneysel çalışmasında, 14 hafta süresince çocuklarla gerçekleştirilen oyunların çocukların koşma, top atma, top tutma, ileri sıçrama, yukarı sıçrama gibi motor becerilerinde artış olduğu sonucuna ulaşılmıştır. Kerkez' in (2006) geliştirdiği oyun ve egzersiz programının çocukların fiziksel ve motor gelişim düzeylerine etkisinin incelendiği çalışmada da, oyun ve egzersiz programının olumsuz çevre koşullarından etkilenen dezavantajlı çocukların fiziksel ve motor özelliklerinin normal standartlara ulaştırmada etkili olduğu saptanmıştır. Oyunun dil gelişimi üzerine etkilerini araştıran Gözalan ve Koçak'ın (2014) çalışmasında ise, geliştirilen oyun temelli dikkat eğitimi programının 60-72 aylık çocukların kelime bilgi düzeylerini arttırmakta etkin bir rol oynadığı tespit edilmiştir. Türkoğlu ve Uslu'nun (2016) oyun temelli bilişsel gelişim programının 60-72 aylık çocukların bilişsel gelişimlerine etkisini inceledikleri araştırmada, 12 hafta boyunca uygulanan program sonucunda programın uygulandığı deney grubu çocuklarının bilişsel gelişim puanlarında anlamlı bir artış olduğu ve etkisinin de kalıcı olduğu sonucuna ulaşılmıştır. Ayrıca Kaya (2010) özel gereksinimli çocuklara oyun müdahale programı uygulamış ve program sonucunda deney grubu özel gereksinimli çocukların bilişsel beceri puanlarının kontrol grubu çocuklarına göre anlamlı derecede yüksek olduğu bulunmuştur. Aynı çalışmada, deney grubunun özel gereksinimli çocukların müdahale öncesinde ve müdahale sonrasında performanslarının da pozitif yönde farklılaştı̆̆ tespit edilmiştir. Oyunun çocuğun sosyal ve duygusal gelişimini etkilediği üzerine yapılmış çalışmalar da bulunmaktadır. Örneğin, Durualp ve Aral (2010) tarafından geliştirilen ve sekiz hafta uygulanan oyun temelli sosyal beceri eğitiminin çocukların sosyal beceri puanlarını anlamlı oranda arttırdığı saptanmıştır. Dolayısı ile oyunun çocukların bütünsel gelişimine katkı sağladığı görülmektedir.

Fakat günümüzde çocukların akranlarıyla birlikte etkileşimli oyunlardan daha çok teknoloji kapsamındaki bilgisayar ya da akıllı telefonlardaki sanal uzamda konsol oyunları, pc oyunları ve çevirim içi oyunlarla oynadığı sıklıkla gözlemlenmektedir. Akçay ve Özcebe (2012) tarafından yürütülen okul öncesi eğitim alan çocukların ve ailelerinin bilgisayar oyunu oynama alışkanlıklarının değerlendirilmesini amaçlayan çalı̧̧ma sonucunda, okul öncesi dönem çocuklarının \%44,1'inin bilgisayar oyunu oynadığı tespit edilmiştir. Gündoğdu ve arkadaşlarının (2016) okul öncesi çocuklarında medya kullanımı üzerine gerçekleştirdikleri tanımlayıcı araştırmalarında ise, çalışmanın örneklemini oluşturan her çocuğun en az bir ya da daha fazla teknolojik aletle, gün içinde 1 saat ya da 1 saatten fazla zaman geçirdikleri tespit edilmiş̧ir. Özellikle çocukların teknolojik aletlerle uğraştıkları zaman diliminin ise çoğunlukla yemek saatleri olduğu sonucuna ulaşılmıştır. Ayrıca geçmiş zamanlarda oynanan geleneksel çocuk oyunları incelendiğinde ise, genellikle çocukların akranları ile oyunlar oynadıkları, günümüz çocuklarının ise genellikle tek başlarına bireysel oyunlar oynadıkları gözlenmektedir. Koçyiğit ve BaydilekBaşara'nın (2015) okul öncesi dönem çocuklarının oyun algılarının incelenmesi üzerine yapmış oldukları çalışmada, çocuklar oyunlarını genelde evde yalnız başlarına oynadıklarını belirtmişlerdir. Toran ve Dilek (2017)'in yapmış oldukları çalışma sonucunda da çocukların kitaplarında da oyuna yer verilmediği gözlemlenmiştir. İncelenen 200 resimli hikaye kitaplarının sadece 18'inde oyun olduğu tespit edilmiştir. Başal (2007) çocuğun yaşamında son derece önemli olan oyunun günümüzde teknolojinin etkisi ile değiştiğini belirtmiştir. İngiltere'de yapılan araştırma sonucunda da benzer sonuçlara ulaşıllmıştır. 12-15 yaş arasındaki çocukların \%26'sının, 8-11 yaş arası çocukların \%18'inin kendi tablet bilgisayarları olduğu, hanehalkının tablet bilgisayara sahip olma durumlarının ise $\% 20$ 'den $\% 50$ 'e çıktı̆̆ı tespit edilmiştir (Given ve ark., 2015).Teknolojinin gelişmesi sonucunda bir yandan yeni oyuncaklar geliştirilirken öte yandan eski geleneksel oyuncaklar ve oyunlar günümüz çocukları tarafindan unutulmaya yüz tutmuştur.

Bu araştırmanın amacı, 60 yaş ve üzeri yetişkinlerin 6-10 yaşları arasında oynamayı en sevdiği oyun özellikleri ile 6-10 yaş arasındaki çocukların günümüzde oynamayı en sevdiği oyunların özelliklerini karşılaş̧ırmaktır. Ana amaç cümlesi doğrultusunda aşağıda belirtilen araştırma sorularına yanıt aranmıştır: 
a. 60 yaş ve üzeri yetişkinlerin 6-10 yaşları arasında oynamayı en sevdiği oyunun özellikleri (oyunun oynandığı alan, oyun oynama şekli, araç kullanımı, oyun grubu gb.) nelerdir?

b. 6-10 yaş arasındaki çocukların günümüzde oynamayı en sevdiği oyunların özellikleri (oyunun oynandı̆̆ı alan, oyun oynama şekli, araç kullanımı, oyun grubu gb.) nelerdir?

c. 60 yaş ve üzeri yetişkinlerin 6-10 yaşları arasında oynamayı en sevdiği oyunun özellikleri ile 6-10 yaş arasındaki çocukların günümüzde oynamayı en sevdiği oyunların özellikleri arasında ne gibi benzerlikler veya farklıliklar vardır?

\section{Yöntem}

\section{Araștırma Modeli}

Bu araștırma, "temel nitel araștırma" yöntemi ile desenlenmiştir. Temel nitel araştırmalar, bir durum ya da olayın doğal ortamında bütüncül ve gerçekçi bir biçimde ortaya konmasını sağlayan araştırmalardır. Temel nitel araştırmalarda veriler; görüşme, gözlem ve doküman analizi gibi nitel veri toplama yöntemleri kullanılarak toplanır (Karataş, 2015). Yetişkinlerin ve çocukların en çok sevdiği oyunların tespitinin ve karşılaştırılmasının yapılması için yarı yapılandırılmış görüşme formları hazırlanarak yarı yapılandırılmış görüşme tekniği kullanılmıştır.

\section{Katılımelar}

Bu çalışmada amaçlı örnekleme yönteminden ölçüt örnekleme kullanılmıştır. Ölçüt örnekleme yönteminde, araştırmanın amacı doğrultusunda araştırmacı tarafından önceden bir dizi ölçütler hazırlanır (Yıldırım ve Şimşek, 2005). $\mathrm{Bu}$ araştırmada yaş baremi ölçüt olarak kullanılmıştır. Çocukların sevdiği oyunların belirlenmesinde 6-10 yaş arası çocuklar, yetişkinlerin çocukken oynamayı sevdiği oyunların tespitinde ise 60 yaş ve üzeri ölçüt olarak belirlenmiş̧tir. Ayrıca örnekleme dâhil edilen her 60 yaş ve üzeri bir yetişkinin ailesinden, 6-10 yaş arası bir çocuk araştırmaya alınmıştır. Aile yapısının özelliklerinden kaynaklı farkın ortadan kaldırılması için gerçekleşen bu durumda katılımcı seçiminde bir ölçüt oluşturmuştur.

Araştırmada ortaya çıkacak oyunların ve oyun özelliklerinin bölgesel ve kültürel farklılıkları da kapsaması için İstanbul Taşınma Hareketliliği Raporu (2016) baz alınmıştır. İstanbul Taşınma Hareketliliği Raporu (2016) doğrultusunda İstanbul Anadolu Yakası'nda en fazla göç alan ilçe Maltepe olduğundan dolayı araştırma, İstanbul ili Maltepe ilçesinde gerçekleştirilmiştir. Milli Eğitim Bakanlığı'na bağlı Maltepe ilçesindeki alt-orta ve üst sosyoekonomik düzeye sahip 3 bağımsız anaokulu ve 3 ilkokul belirlenmiştir. Belirlenen okullardan 6-10 yaş arası 99 çocuk ve aynı çocukların ailelerinden 60 ve üzeri yaşa sahip 99 yetişkin olmak üzere toplam 198 kişi çalışmaya dâhil edilmiştir. Araştırma kapsamına alınan katılımcıların demografik bilgileri Tablo 1'de verilmiştir.

Tablo 1. Katılımcılara Ait Demografik Bilgiler

\begin{tabular}{|c|c|c|c|c|c|c|c|}
\hline \multicolumn{4}{|c|}{ Yetişkine Ait Bilgiler } & \multicolumn{4}{|c|}{ Çocuklara Ait Bilgiler } \\
\hline & & $\mathbf{n}$ & $\%$ & & & $\mathbf{n}$ & $\%$ \\
\hline \multirow{3}{*}{ Cinsiyet } & Erkek & 52 & 52,53 & \multirow{3}{*}{ Cinsiyet } & Erkek & 51 & 51,52 \\
\hline & Kadın & 47 & 47,47 & & Kız & 48 & 48,48 \\
\hline & Toplam & 99 & 100 & & Toplam & 99 & 100 \\
\hline \multirow{6}{*}{$\begin{array}{c}\text { Öğrenim } \\
\text { Düzeyi }\end{array}$} & Öğrenimi Yok & 20 & 20,20 & Öğrenim & Okulöncesi & 22 & 22,22 \\
\hline & İlkokul & 54 & 54,55 & Gördüğü & İlkokul & 77 & 77,78 \\
\hline & Ortaokul & 8 & 8,08 & Düzey & Toplam & 99 & 100 \\
\hline & Lise & 11 & 11,11 & & & & \\
\hline & Üniversite & 6 & 6,06 & & & & \\
\hline & Toplam & 99 & 100 & & & & \\
\hline
\end{tabular}

Tablo 1 incelendiğinde, araştırmaya katılan yetişkinlerin $\% 52,53$ 'ünün erkek, \%47,47'sinin kadın olduğu, $\% 54,55$ 'inin ilkokul, \%11,11'inin lise, \%8,08'inin ortaokul ve \%6,06'sının üniversite mezunu olduğu ve öte yandan \%20,20'sinin ise bir öğrenim almadığı tespit edilmiştir. Araştırmanın bir diğer basamağını oluşturan çocukların yüzde frekansları incelendiğinde ise, araştırmaya katılan çocukların \%51,52'sinin erkek, \%48,48'inin kız olduğu ve \%77,78'i ilkokula, \%22,22'sinin ise okulöncesi eğitim kurumuna devam ettiği saptanmıştır. Ayrıca araştırmaya katılan yetişkinlerin yaş ortalamasının 68,01 yıl, çocukların yaş ortalamasının ise 7,98 yıl olduğu belirlenmiş̧tir. 


\section{Veri Toplama Araçları}

Araştırmada, yetişkinlerin ve çocukların en sevdiği oyunların belirlenmesi amacıyla hem çocuklar için hem de yetişkinler için ayrı ayrı hazırlanmış "Oyun Belirleme Görüşme Formları" kullanılmıştır. Yetişkinlere dair hazırlanmış görüşme formunda, cinsiyet, yaş ve öğrenim durumu gibi demografik bilgiler yer alırken, çocuklara dair hazırlanan formda ise çocuğun yaşı ve öğrenim gördüğü okul düzeyi demografik bilgi sorularına yer verilmiştir. Oyun Belirleme Çocuk Görüşme Formu'nda çocukların en sevdiği oyunların belirlenmesi amaciyla 2 açık uçlu soru bulunmaktadır. Bu sorular: "En sevdiğin oyun hangisidir?" ve "Bize bu oyunu anlatır mısın?"dır. Oyun Belirleme Yetişkin Görüşme Formu'nda ise "6-10 yaşları arasında en sevdiğiniz oyun hangisiydi?" ve "Bize bu oyunu anlatır mısınız?" soruları bulunmaktadır.

Veri toplama sürecine başlamadan önce araştırmacılar tarafından hazırlanan Oyun Belirleme Yetişkin ve Çocuk Görüşme Formları eğitim ve oyun alanlarında uzman 2 öğretim üyesine uzman görüşü almak üzere sunulmuştur. Uzman görüşleri doğrultusunda formlar son halini almıştır. Ayrıca çalışma grubunun özelliklerine uygun ön pilot çalışma gerçekleştirilmiştir. Anlamsal ve yapısal anlaşılırlığın sağlanıp sağlanmadığına dair gerçekleştirilen ön pilot çalışma, 6-10 yaş arasında 5 çocuk ve 60 yaş ve üstü 5 yetişkinle gerçekleştirilmiştir.

\section{Verilerin Toplanması}

Araştırma Kasım 2015-Şubat 2016 tarihleri arasında gerçekleştirilmiştir. Araştırma kapsamında Maltepe ilçesinde yaşayan 60 yaş ve üzeri yetişkinler ve 6-10 yaş arası çocuklar ile yüz yüze görüşmeler gerçekleştirmiştir. Çocuklarla yapılan görüşmeler, çocukların kendi okullarında ve kimseden etkilenmemesi için sınıflarından ayrı bir yerinde gerçekleştirilmiş̧ir. Çocukların 60 ve üzeri yaşa sahip ebeveynleri ile ilgili yapılacak görüşmelerden önce, telefonla randevular alınmıştır. Randevu tarih ve saatleri belirlenerek çocukların okullarında yetişkinlerle bireysel görüşmeler gerçekleştirilmiştir. Ortalama olarak her bir katılımcı ile 5 dakikalık görüşmeler yapılmıştır. Araştırmacı, görüşmelerde yarı yapılandırılmış görüşme formu içerisindeki soruları katılımcılara yöneltilmiştir. Katılımcıların vermiş olduğu yanıtlar ise görüşme formunun üzerindeki önceden belirlenen boş alanlara yazılmıştır. Çocuklardan ve yetişkinlerden alınan oyunlar görüşmeyi gerçekleştiren araştırmacı tarafından bilinmiyor ise sondaj soruları sorularak oyunun özellikleri ayrıntılarıyla ortaya çıkartılmışıtır.

\section{Verilerin Analizi}

Araştırma kapsamına dahil edilen yetişkinlerin ve çocukların vermiş̧ oldukları yanıtlar içerik analizi tekniği kullanılarak çözümlenmiştir. İçerik analizinde çok sayıda metin içeriğinin ortak özelliklerini ortaya çıkartmak amacıyla, önemli olan anlamların yapılandırılmasına yönelik, nitelden nicele doğru genelleştirmeye imkan veren bir tekniktir (Gökçe, 2006).

Araştırmaya katılan yetişkin ve çocukların kimlikleri gizli tutulması amacıyla kodlama sistemine gidilmiştir. Yetişkinler "Y", çocuklar ise "Ç" olarak kodlanmıştır. Kodun yanında bulunan sayı ise görüşme sırasında forma verilen sıra numarasidır.

Araştırmada veri inanırlığının sağlanması amacıyla "kodlayıcı arası görüş birliği" ilkesi kullanılmıştır. Veri analizi sürecinde yetişkinlerin ve çocukların vermiş olduğu cevaplar 2 araştırmacı tarafından, birbirinden bağımsız olarak değerlendirilmiştir ve ortaya çıkartılan kodlarla kategoriler oluşturulmuştur. Ardından araştırmacılar bir araya gelerek gözlemciler arası tutarlılık hesaplanmıştır. Gözlemciler arası tutarlılık, tutarlı olan maddelerin sayısının toplam madde sayısına bölünüp, 100 ile çarpımıyla elde edilmektedir (Creswell, 2013). Çalışma kapsamında gözlemciler arası tutarlılık \%93,11 olarak hesaplanmıştır.

\section{Bulgular}

Araştırma kapsamında analiz gerçekleştirilirken yetişkinler ve çocuklar tarafından belirtilen oyunlar; oyunun oynandığı alan (dış alan, iç alan), oyunun oynanma şekli (hareketli oyun, hareket gerektirmeyen oyun), oyun içinde araç kullanımı (araçlı oyun, teknolojik araçlı oyun, araçsız oyun), oyun grubu (bireysel oyun, grup oyunları), yaratıcılık (yapılandırılmış araçlar, yapılandııılmamış araç, araçsız oyun), ebe bulunma durumu (ebe bulunan oyunlar, ebe bulunmayan oyunlar) ve tekerleme bulunma durumu (tekerlemeli oyunlar, tekerleme bulunmayan oyunlar) açısından incelenmiştir.

60 Yaş ve Üzeri Yetişkinlerin 6-10 Yaşları Arasında Oynamayı En Sevdiği Oyun Özellikleri Nelerdir? 
Araştırmanın çalışma grubuna dahil edilen 60 yaş ve üstü yetişkinlere Oyun Belirleme Yetişkin Görüşme Formu kapsamındaki "6-10 yaşları arasında en sevdiğiniz oyun hangisiydi?" ve "Bize bu oyunu anlatır mısınız?" soruları analiz edilmiştir. Yetişkinlerin vermiş olduğu yanıtların içerik analiz sonuçları Tablo 2'de verişmiştir.

Tablo 2. 60 Yaş ve Üzeri Yetişkinlerin 6-10 Yaşları Arasında Oynamayı En Sevdiği Oyunun Özellikleri

\begin{tabular}{llrr} 
& & n & \% \\
\hline Oyunun Oynandı̆̆ı Alan & Diş Alan & 85 & 85,86 \\
& İç Alan & 14 & 14,14 \\
& Toplam & 99 & 100 \\
\hline Oyunun Oynanış Şekli & Hareketli Oyun & 63 & 63,64 \\
& Hareket Gerektirmeyen Oyun & 36 & 36,36 \\
& Toplam & 99 & 100 \\
\hline Oyun İçinde Araç Kullanımı & Araç Kullanılan Oyunlar & 75 & 75,76 \\
& Teknolojik Araçlar & - & - \\
& Araçsız Oyunlar & 24 & 24,24 \\
& Toplam & 99 & 100 \\
\hline Kullanılan Aracın Yapılandırılışı & Yapılandırılmış Araçlar & 11 & 11,11 \\
& Yapılandırılmamış Araçlar & 64 & 64,65 \\
& Araç Bulunmamakta & 24 & 24,24 \\
& Toplam & 99 & 100 \\
\hline Oyun Grubu & Bireysel Oyunlar & 8 & 8,08 \\
& Grup Oyunları & 91 & 91,92 \\
& Toplam & 99 & 100 \\
\hline Ebe Bulunma Durumu & Ebe Bulunmakta & 34 & 34,34 \\
& Ebe Bulunmamakta & 65 & 65,66 \\
& Toplam & 99 & 100 \\
\hline Tekerleme Bulunma Durumu & Tekerleme Bulunmakta & 19 & 19,19 \\
& Tekerleme Bulunmamakta & 80 & 80,81 \\
& Toplam & 99 & 100 \\
\hline & & &
\end{tabular}

Tablo 2 incelendiğinde, 60 yaş ve üzerindeki yetişkinlerin 6-10 yaş arasında oynamayı en sevdiği oyunların \%85,86'sının diş alanda, \%14,14'ünün iç alanda oynanan oyunlar olduğu sonucuna ulaşılmıştır. Yetişkinlerin çocukken oynadıkları oyunların \%63,64'ünün hareketli, \%36,36'sının hareket gerektirmeyen özellikte olduğu saptanmıştır. Ayrıca oyunların, \%75,76'sında araç kullanıldığı ve bu araçların \%11,11'inin yapılandırılmış, \%64,65'inin ise yapılandırılmamış özellikte araç olduğu tespit edilmiştir. Oyun grubu özelliğine göre incelendiğinde ise, oyunların \%91,92'sinin grup ile oynanma, \%8,08'inin bireysel oynanma özelliğine sahip olduğu sonucuna ulaşılmıştır. Oyunların içeriğinde ebe bulunma durumuna göre, oyunların \%65,66'sında ebe bulunurken, \%34,34'ünde ebe bulunmamaktadır. Oyunların \%80,81'inde tekerleme bulunmamaktayken, \%19,19'unda tekerleme bulunduğu görülmüştür.

Y71- "En sevdiğim oyun uzuneşekti. Beş ya da daha çok arkadaşla bu oyunu oynuyorduk. Oyun başlamadan önce bir arkadaşı yastık seçiyorduk. Bu arkadaş sırtını duvara yaslıyordu. Üç arkadaş eşek gibi eğilerek yastık olan arkadaşın ayaklarının arasına kafasını sokarak sıralanıyorduk. Beşinci arkadaş ilk sıradaki üzerine atlayabilmek için uzaktan koşarak geliyor ve zıplayarak 1. arkadaşın üzerine ulaşmaya çalışıyordu. ” (77 yaş, Erkek)

Y22- "En sevdiğim oyun kırık testiden inek yapmaktı. Testiyi parçalara ayırıp inek modeli veriyorduk. İçine su koyunca inekten süt să̆armış gibi görüntü oluşurdu.” (78 yaş, Kadın)

Y90- “Elim Elim Öpülek oyununu çok severdim. Arkadaşlarımla yuvarlak olacak şekilde otururduk ve herkes ellerini açıp yere koyardı. Bir ebe seçilirdi ve o yerdeki ellerin parmaklarını tek tek saymaya başlardı. Sayarken; "Elim elim öpülek/Elden çıkan töpülek/Töpüldeğin yarısı/Kara koyun derisi/Al bunu, çıkar bunu” derdik. Sonra kimin parmağında kalmışsak o parmağını kıvırıp 
elin altına alınır. Daha sonra bu şekilde devam edilir ve parmakları biten kişiler tek tek oyundan çıkardı. En son kalan kişi oyunu kazanırdı." (80 yaş, Kadın)

Y10- "Buz üstünde aşık oyunu. Koyunların bacaklarından çılkarllan aşılkları biriktirirdik. Yaklaşık 20-25 tane. Buzun ortasına yuvarlak çizip, toplanılan aşıklar o yuvarlağın içine dizilir. Sonra yuvarlaktan 10 adım geriye gidilir. Beş arkadaşs sirayla elindeki aşıklarla yuvarlak içindeki aşıkları vurmaya çalışırdı. Kim daha çok aşık vurduysa oyunu o kazanırdl." (73 yaş, Erkek)

\section{6-10 Yaş Arasındaki Çocukların Günümüzde Oynamayı En Sevdiği Oyun Özellikleri Nelerdir?}

6-10 yaş arasındaki çocukların Oyun Belirleme Çocuk Görüşme Formu kapsamındaki "En sevdiğin oyun hangisidir?" ve "Bize bu oyunu anlatır mısın?" soruları analiz edilmiştir. Çocukların vermiş olduğu yanıtların içerik analiz sonuçları Tablo 3’te verişmiş̧tir.

Tablo 3. 6-10 Yaş Arasındaki Çocukların Oynamayı En Sevdiği Oyunun Özellikleri

\begin{tabular}{llrr} 
& & n & $\mathbf{\%}$ \\
\hline Oyunun Oynandığı Alan & Dış Alan & 36 & 36,37 \\
& İç Alan & 63 & 63,63 \\
& Toplam & 99 & 100 \\
\hline Oyunun Oynanış Şekli & Hareketli Oyun & 43 & 43,43 \\
& Hareket Gerektirmeyen Oyun & 56 & 56,57 \\
& Toplam & 99 & 100 \\
\hline Oyun İçinde Araç Kullanımı & Araç Kullanılan Oyunlar & 31 & 31,32 \\
& Teknolojik Araçlar & 34 & 34,34 \\
& Araçsız Oyunlar & 34 & 34,34 \\
& Toplam & 99 & 100 \\
\hline Kullanılan Aracın Yapılandırılışı & Yapılandırılmış Araçlar & 60 & 60,61 \\
& Yapılandırılmamış Araçlar & 5 & 5,05 \\
& Araç Bulunmamakta & 34 & 34,34 \\
& Toplam & 99 & 100 \\
\hline Oyun Grubu & Bireysel Oyunlar & 49 & 49,49 \\
& Grup Oyunları & 50 & 50,51 \\
& Toplam & 99 & 100 \\
\hline Ebe Bulunma Durumu & Ebe Bulunmakta & 32 & 32,32 \\
& Ebe Bulunmamakta & 67 & 67,68 \\
& Toplam & 99 & 100 \\
\hline Tekerleme Bulunma Durumu & Tekerleme Bulunmakta & 11 & 11,11 \\
& Tekerleme Bulunmamakta & 88 & 88,89 \\
& Toplam & 99 & 100 \\
\hline
\end{tabular}

Tablo 3 incelendiğinde, çocukların günümüzde en sevdiği oyunların oynanma alanına göre \%63,63'ünün iç alanda, \%36,37'sinin dış alanda oynandığı, oyunun oynanış şekline göre \%56,57'sinin hareket gerektirmeyen oyun, $\% 43,43$ 'ünün hareketli oyun özelliğinde olduğu, oyun grubu özelliğine göre $\% 50,51$ 'inin grupla oynandığı, $\% 49,49$ 'unun bireysel oynandığı, ebe bulunma durumuna göre $\% 67,68$ 'ininde ebenin bulunmadığ $1, \% 32,32$ 'sinde ebenin bulunduğu ve tekerleme bulunma durumuna göre ise oyunların $\% 88,89$ 'unda tekerlemenin bulunmadığı, $\% 11,11$ 'inde tekerlemenin bulunduğu sonucuna ulaşılmıştır. Çocukların belirttiği oyunların içeriğinde araç kullanım durumları incelendiğinde ise, tüm oyunların \%65,66'sında araç kullandığ 1 ve kullanılan araçların ise \%34,34'ünün teknolojik araçlar olduğu tespit edilmiştir.

Ç44. "En sevdiğim oyun Winx.Tabletten oynanıyor. Önce bir kişi seçip onu giydirdikten sonra baş̧aların yaratıyorsun. Ama bölümleri atlamak için para kazanman gerekiyor ve yarattı̆̆ın kişi eğer beğenmezse üstünü baştan yaratiyorsun.” (7 yaş, Kız) 
Ç69. “ En sevdiğim oyun Subway Surf. Trenlere çarpmadan polisten kaçıyorsun. Sonra altınları topluyorsun. Altınları biriktirip insan veya eşya alabiliyorsun. Ondan sonra kutular toplayıp hediye kazanıyorsun. Kutuların içinden kaykay, para, şapka ve uçma hakkı çıkıyor.” (6 yaş, Erkek)

Ç9. "Polisçilik oynamayı seviyorum. Grup halinde oynanır. Grubun yarısı polis yarısı hırsız olur. Polislerin ellerinde silah olur ve hırsızları yakalayıp onları öldürürler. En çok öldüren kişiye oyun sonunda ödül verilir.” (9 yaş, Erkek).

Ç56. “ En sevdiğim oyun Barbi bebeğimi giydirip, onunla parka gitmek.” (6 yaş, Kız)

Ç91. " En sevdiğim oyun kulaktan kulağa. Çocuklar yan yana geçer. En baştakine bir kelime söylenir. Söylenen kelimeyi arkasındakine söyler. O da onun arkasındakine. En sondaki kişi kelimeyi doğru söylemeye çalışır. ” (6 yaş, K1z)

Ç99. "Doktor oyunu. Oyun 10 kişi ile oynanır. Kişiler arasında seçim yapılır, seçilen kişi doktor olur geriye kalanlar otururlar. Doktor ayakta kalır. Doktor içinden bir sayı tutar 10 a kadar. Sonra herkesten bir sayı söylemesini ister, doktorun tuttuğu sayıy bilen kişi onun yanına gider ve beraber sayı tutup geriye kalan 8 kişiye sorarlar. Aynı şekilde son bir kişi kalana kadar oyun devam eder." (10 yaş, Erkek)

60 Yaş ve Üzeri Yetişkinlerin 6-10 Yaşları Arasında Oynamayı En Sevdiği Oyunun Özellikleri İle 6-10 Yaş Arasındaki Çocukların Günümüzde Oynamayı En Sevdiği Oyunların Özellikleri Arasında Ne Gibi Benzerlikler veya Farklılıklar Vardır?

60 yaş ve üzeri yetişkinlerin çocukluk döneminde oynamayı sevdiği oyunlar ile günümüzdeki çocukların oynamayı sevdiği oyunların özellikleri karşılaştırılmalı olarak Tablo 4'te verilmiştir.

Tablo 4. Yetişkinlerin ve Çocukların Oynamayı Sevdiği Oyun Özelliklerinin Karşılaştırılması

\begin{tabular}{llrrrr} 
& & \multicolumn{3}{c}{ Yetişkin } & \multicolumn{2}{c}{ Çocuk } \\
\cline { 2 - 5 } Oyunun Oynandığı Alan & Diş Alan & n & \% & n & \% \\
& İç Alan & 85 & 85,86 & 36 & 36,37 \\
& Toplam & 14 & 14,14 & 63 & 63,63 \\
& Hareketli Oyun & 99 & 100 & 99 & 100 \\
\hline Oyunun Oynanış Şekli & Hareket Gerektirmeyen Oyun & 63 & 63,64 & 43 & 43,43 \\
& Toplam & 36 & 36,36 & 56 & 56,57 \\
& Araç Kullanılan Oyunlar & 99 & 100 & 99 & 100 \\
\hline Oyun İçinde Araç Kullanımı & Teknolojik Araçlar & 75 & 75,76 & 31 & 31,32 \\
& Araçsız Oyunlar & - & - & 34 & 34,34 \\
& Toplam & 24 & 24,24 & 34 & 34,34 \\
& Yapılandırılmış Araçlar & 99 & 100 & 99 & 100 \\
\hline Kullanılan Aracın Yapılandırılışı & Yapılandırılmamış Araçlar & 11 & 11,11 & 60 & 60,61 \\
& Araç Bulunmamakta & 64 & 64,65 & 5 & 5,05 \\
& Toplam & 24 & 24,24 & 34 & 34,34 \\
& Bireysel Oyunlar & 99 & 100 & 99 & 100 \\
\hline Oyun Grubu & Grup Oyunları & 8 & 8,08 & 49 & 49,49 \\
& Toplam & 91 & 91,92 & 50 & 50,51 \\
& Ebe Bulunmakta & 99 & 100 & 99 & 100 \\
\hline Ebe Bulunma Durumu & Ebe Bulunmamakta & 34 & 34,34 & 32 & 32,32 \\
& Toplam & 65 & 65,66 & 67 & 67,68 \\
& Tekerleme Bulunmakta & 99 & 100 & 99 & 100 \\
\hline Tekerleme Bulunma Durumu & Tekerleme Bulunmamakta & 19 & 19,19 & 11 & 11,11 \\
& Toplam & 80 & 80,81 & 88 & 88,89 \\
& & 99 & 100 & 99 & 100 \\
\hline
\end{tabular}


Tablo 4 incelendiğinde, çalışma grubuna dahil edilen yetişkinlerin çocukken oynamayı sevdiği oyunların $\% 85,86$ 'sının dış alanda, \%14,14'ünün iç alanda oynanma özelliğine sahip olduğu saptanırken, günümüz çocuklarının en sevdiği oyunların sadece \%36,37'sinin dış alanda, \%63,63'ünün ise iç alanda oynanma özelliğine sahip olduğu sonucuna ulaşılmıştır. Bir diğer ifade ile, yetişkinler 6-10 yaşlarında iken en sevdikleri oyunların çoğunlukla açık alanda gerçekleştiğini belirtirken, günümüz çocukların ise en sevdiği oyunların çoğunluğunun iç alanda olduğu saptanmıştır. Yetişkinlerin çocukken en çok sevdiği oyunların yarısından fazlasının $(\% 63,64)$ hareketli oyunlar olduğu tespit edilmiştir. Fakat çalışma grubundaki çocukların en sevdiği oyunların yarısından fazlasının $(\% 56,57)$ hareket gerektirmeyen özellikte olduğu sonucuna ulaşılmıştır.

Yetişkinlerin çocukken oynamış olduğu oyun özellikleri ile günümüz çocuklarının oynamayı sevdiği oyun özellikleri arasındaki en büyük farklılıklardan birisi de oyun içinde kullanılan araç seçimidir. Günümüz çocuklarının \%34,34'ünün en sevdiği oyunların teknolojik araçlar vasıtası ile gerçekleştirildiği tespit edilmiştir. Yetişkinlerin çocukluk oyunlarında \%75,76'sında araç kullanıldığı ve bu oyunların hiçbirinde teknolojik araç olmadığı sonucuna ulaşılmıştır. Ayrıca yetişkinlerin çocukken oynadığı oyunlarda kullandığı araçlar incelendiğinde, $\% 64,65$ 'inin yapılandırılmamış araçlar olduğu görülmüştür. Bir diğer ifade ile yetişkinler çocukken oynamayı en sevdiği oyunlarda bir tahta parçasını, taşı, kemik parçasını veya gazoz kapaklarını bir oyun aracı olarak kullanırken, günümüz çocuklarının ise büyük bir oranının bir amaç çerçevesinde oluşturulmuş araçları oyunlarında kullanmaktadır.

Yetişkinler ile yapılan görüşme sonucunda belirttikleri oyunların tamamına yakınında $(\% 91,92)$ grupla oynanma özelliği varken, günümüz çocuklarının en sevdiği oyunların sadece \%50,51'inin grupla oynanan oyunlar olduğu sonucuna ulaşılmıştır. Bir diğer ifade ile günümüz çocuklarının en sevdiği oyunlarda yarısına yakının bireysel oynanan oyunlar olduğu tespit edilmiş̧ir. Ayrıca oyunların içeriğinde ebe bulunma durumları ve tekerleme bulunma durumları incelendiğinde ise, yetişkinlerin çocukken oynadıkları oyun özellikleri ile günümüz çocukların oynamayı sevdiği oyun özellikleri arasında benzer oranların çıktığı görülmüş̧ür. Yetişkinlerin belirtmiş olduğu oyunların \%34,34'ünde ebe bulunurken, çocuklarınkinde ise \%32,32'sinde ebe bulunduğu saptanmıştır. Tekerleme bulunma durumuna göre ise, yetişkinlerin oyunlarının \%19,19'unda, çocukların oyunlarının ise $\% 11,11$ 'inde tekerleme içerdiği sonucuna ulaşılmıştır.

\section{Tartışma ve Sonuç}

60 yaş ve üzeri yetişkinlerin 6-10 yaşları arasında oynamayı en sevdiği oyun özellikleri ile 6-10 yaş arasındaki çocukların günümüzde oynamayı en sevdiği oyun özelliklerini karşılaştırmalı olarak incelemek amacıyla yapılan bu araştırmada, ortaya çıkan sonuçlardan birisi oyunun oynandığı alanın farklılaştığıdır. Çalışma sonucunda yetişkinlerin çocukken en sevdiği oyunların çoğunun dış alanda oynandığı, günümüz çocuklarının oyunlarının ise yarısından fazlasının iç alanda oynandığı sonucuna ulaşılmıştır. Fleer (2014)'in öğretmenlerle ve Clements (2004)'in anneler ile yaptığı çalışmada, hem öğretmenler hem de anneler günümüzdeki çocuklarla karşılaştıııldığında kendi çocukluklarında açık alanlarda daha fazla oyun oynadıklarını belirtmişlerdir.

Günümüz çocuklarının dış alanda daha az oyun oynamasının nedeninin ebeveynlerin dış alan ile ilgili kaygılarından kaynaklı olabileceği düşünülebilir. Cevher-Kalburan (2014) Denizli ilindeki okul öncesi eğitim kurumlarına devam eden çocukların dış mekanda oyun oynama fırsatlarının ve ebeveynlerin bu konudaki görüşlerini belirlemek amacıyla yaptıkları çalışma sonucunda, ebeveynlerin dış mekanda çocukların oyun oynama konusunda kaygıları olduğu sonucuna ulaşmışlardır. Özellikle ebeveynler trafik, kötü niyetli yabancılar, kaçırılma ve yaralanma gibi durumların olabileceğine dair kaygılarını dile getirmişlerdir. Veitch, Bagley, Ball ve Salmon'un (2006) Avusturalya'daki düşük, orta ve yüksek sosyo-ekonomik duruma sahip ebeveynlerin çocuklarının nerede ve neden oynadıklarına dair algılarını belirlemeye çalışıkları araştırmasında da benzer sonuçlara rastlanmıştır. Çalışmaya katılan 78 ebeveynin görüşleri doğrultusunda, ebeveynlerin \%94'ünün oyun alanlarının güvenirliliği açısından endişeleri oldukları sonucuna ulaşılmışıı. Endişelerine sebep olan nedenleri ise, yabancı kişiler, gençler ve araç trafiğine yakın olma olarak sıralamışlardır. Deretarla-Gül'ün (2012) oyun bahçelerinde yer alan materyallerin ve oyun alan özelliklerinin ebeveynler tarafından değerlendirmesine yönelik çalışmasında da, ebeveynlerin çocukları ile gittikleri oyun parklarını tercih etme nedenleri arasında ikinci sırada $\% 36,6$ oranında oyun parklarının güvenli bir yerde olması yer almaktadır. Fleer (2014) tarafından gerçekleştirilen çalışmada da, öğretmenlerin kendi çocukluklarında oynadıkları oyunlar hakkında görüşleri alınmıştır. Öğretmenler kendi ebeveynlerinin onlar oyun oynarken çok fazla güvenlik kaygısı duymadıklarını ancak günümüzde ebeveynlerin 
daha fazla kaygı duyduklarını ifade etmişlerdir. Clements (2004) de çalışmasında günümüz çocuklarının bir önceki nesile göre daha az dış mekan oyunu oynamasını televizyon ve dijital medyaya bağımlılık, suç ve güvenlik ile ilgili endişeler olarak öne sürmüştür.

Günümüz çocuklarının oyunlarının yarısından fazlasının iç alanda oynandığı sonucunun bir başka nedeni ise formal eğitim programlarında dış alanda oyun etkinliklerine çok fazla yer verilmemesi olduğu düşünülebilir. Alat, Akgümüş ve Cavalı'nın (2012) okul öncesi öğretmenlerinin açık alan etkinlikleri hakkındaki tutum, düşünce ve uygulamalarını ortaya çıkarmak amacıyla yapmış oldukları çalışma sonucunda, öğretmenlerin açık hava etkinliklerine karşı olumlu düşünce ve tutumlara sahip olduğu belirlenmiştir. Fakat uygulama kısmına gelindiğinde dış alanın fiziki şartlarının yetersizliği, okul bahçesindeki güvenlik tedbirlerinin azlığı, sınıflardaki çocuk sayısının fazlalığı, çocukların hava koşullarından dolayı hasta olacaklarına dair kaygıları ve ebeveynlerin olumsuz tepkileri gibi sebeplerden dolayı açık hava etkinliklerine yer verilmediği sonucuna ulaşılmıştır. Çelik (2012) tarafından Kocaeli'ndeki okul öncesi eğitim kurumları, çocuk oyun alanlarının niteliği açısından araştırılmış ve 9 okul öncesi eğitim kurumu incelenmiştir. Araştırma sonucunda okul öncesi eğitim kurumlarında bulunan açık alanların etkin olarak kullanılmadığı, mevcut açık alanların çocukların oyunlarına uygun olmadığı ve fiziksel düzenleme konularında eksikliklerin olduğu tespit edilmiştir.

Çocukların oyunlarının yarısından fazlasının iç alanda oynandığı sonucunun bir başka nedeni ise okul öncesi eğitime bakış açısı ve okul öncesi eğitimden beklentiler olabilir. Fleer $(2013 ; 2010)$ ailelerin okul öncesi eğitimde akademik ağırlıklı etkinliklerden daha çok memun olduklarını belirlemiştir. Dolayısı ile öğretmenlerin okul öncesi eğitimde daha çok akademik etkinliklere ağıllık vermekte oldukları ve bununda çocukların oyun davranışlarını azaltmada etkili olduğu düşünülebilir. Miller ve Almon (2009), Amerika'daki pek çok okul öncesi eğitim kurumunda çocukların artık oyun ve keşif yoluyla öğrenmekten, bedenlerini ve hayal güçlerini kullanmaktan çok okuryazarlık ve matematiğe daha fazla zaman harcadıklarını belirtmiştir ve birçok çocuk, gelişim açısından uygunsuz olan akademik standartlara uymak için mücadele etmek zorunda kalmaktadır. Aynı durum ülkemizde de söz konusudur. Tedmem'in 2016 yılında yayınladığı "Anaokulları İlkokul Birinci Sınıflara mı Dönüştü?" başlıklı raporuna göre, anaokulları giderek oyun odaklı uygulamalardan uzaklaşmakta ve gittikçe akademik becerilere yoğunlaşmaktadır. Nicolopoulou (2010)' da makalesinde anaokullarının oyundan gittikçe uzaklaştığını belirtmiştir.

Öte yandan, etkinlikleri oyun temelli planlamamak ve çocukları uzun süreler hareketsiz olmaya sevk etme de çocukların oyun davranışlarını etkileyebilmektedir. Dale ve arkadaşları (2000) yapmış oldukları çalışmada, okulda uzun süre hareketsiz oturan çocukların evde de hareket etmeme eğilimde olduklarını belirtmişlerdir. $\mathrm{Bu}$ hareketsizliğe alışmak, çocukları dış mekanda oyun oynamaktan alıkoyup teknolojik aletler ile oynamak ve televizyon izlemeye itmede güçlü bir etken olarak belirlenmiștir. Araştırmanın bir diğer sonucu olan, yetişkinlerin çocuklukta oynadıkları oyunların yarısından fazlasının hareketli olduğu, günümüz çocukların oyunlarının ise yarısından fazlasının hareket getirmeyen özellikte olduğu bulgusu da bu görüşü desteklemektedir. Clements (2004), Amerika'daki çocukların bir önceki nesile göre daha az hareket içeren oyunlar oynadıklarını belirtmiştir. $\mathrm{Bu}$ durumun nedeni çocukların hareketsiz yaşam tarzı ile ilişkilendirilebilir. Kudaş, Ülkar, Erdoğan ve Çırçı'nın (2005) Ankara ilinde yaşayan 11-12 yaş çocuklarındaki fiziksel aktivitelerini ve beslenme alışkanlıklarını inceledikleri çalışma sonucunda, özellikle çocukların okul saatlerinde fiziksel aktivite düzeylerinde önemli bir düşüşün olduğu saptanmıştır. Türkiye Beslenme ve Sağlık Araştırması (2010) sonuçlarına göre de, Türkiye genelinde 6-11 yaş grubu çocukların \%58,4'ü düzenli olarak yani günde 30 dakika ve daha fazla süre ile herhangi bir egzersiz yapmadığı sonucuna ulaşılmıştır. Egzersiz yapmayanların oranı 6-8 yaş grubunda \%65,8, 9-11 yaş grubunda ise \%52,7 olduğu belirlenmiştir. Bodrova ve Leong, (2003) ve Pica (2003) çalışmalarında çocukların bir önceki nesile göre daha hareketsiz olduklarını ve artan bir şekilde çocukluk çağı obezitesine dikkat çekmişlerdir.

Günümüz çocuklarının sevdiği oyunların yarısından fazlasının iç alanda oynanma özelliğine sahip olmasındaki bir başka nedende dış alanda oyun oynanacak alanların azlığı olabilir. Şener'in (2001) yapmış olduğu çalışmada, oyun alanlarının ve okul bahçelerinin kullanılabilirliği araştırılmıştır. İstanbul ilinde farklı gelir durumuna sahip üç semtte anket çalışması yapılmış ve anket sonuçlarına göre çocukların oyun alanına ihtiyaçları olduğu ve okul bahçelerinin okul dışı zamanlarında kullanılmadığı sonucu ortaya çıkmıştır. Gönen ve Saranlı (2014) okul öncesi eğitim kurumlarının kapalı ve açık hareket alanlarının yeterliliğini araştırmak üzere bir araştırma gerçekleştirmişlerdir. Araştırma sonuçları incelendiğinde örnekleme aldıkları okul öncesi kurumlarının neredeyse hepsinde çocukların hareket gelişimi için ayrılmış bir alanın olduğu fakat bu alanların etkin olarak yapılandırılamadığı sonucuna ulaşılmıştır. Ayrıca açık alanların zemin malzemesinin çocukların sağlıklı hareket 
etmelerine elverişli olmadığı da tespit edilmiştir. Koçan'ın (2012) çocuk oyun alanlarının yeterliliği üzerine gerçekleştirildiği araştırmada, çocuk oyun alanı ve açık yeşil alanda çocuk başına $10 \mathrm{~m}^{2}$ alan düşmesi gerekirken, mevcut alanlarda çocuk başına $2 \mathrm{~m}^{2}$ alan düştüğü sonucuna ulaşılmıştır.

Araştırmada elde edilen bir başka sonuç ise, yetişkin oyunlarının tamamına yakını $(\% 91,92)$ grup oyunu iken; günümüz çocuklarının en sevdiği oyunların sadece \%50,51'inin grupla oynanan oyunlar olduğu sonucudur. Bir diğer ifade ile günümüz çocuklarının yarısına yakını bireysel oynanan oyunları daha çok sevmektedirler. Bunun pek çok nedeni olabilir. Nedenlerden ilki, çekirdek aile yapısının yaygınlaşması ve buna bağlı olarak çocukların evde ancak kardeşleri varsa onlar ile grup oyunu kurmasıdır. Öte yandan, evde tek çocuk olmakta bir etken sayılabilir. Taylı (2007) tarafından yapılan araştırmada kardeşli ve tek çocukların sosyal oyun tercihleri incelendiğinde, kardeşli çocukların tek çocuklara göre daha fazla birlikte ve işbirlikçi oyunu tercih ettikleri belirlenmiştir. Bir başka deyişle, tek çocuklar yalnız oyunu daha fazla tercih etmektedirler. Ayrıca, mahalle kültürünün eskisi kadar yoğun yaşanmayışı, komşuluk gibi değerlerin unutulması, birbirlerine yaşıt komşu çocuklarının birbirlerinin varlığından bile haberdar olmayışı gibi etkenler de çocukların bireysel oyunları tercih etmelerinde önemli bir faktör olabilir.

Çocukların grup oyunları yerine bireysel oyunları tercih etmelerinde teknoloji kullanım düzeyinin artması, televizyon, tablet, cep telefonu gibi aletlerin arkadaşların yerini alması da bir başka etken olarak görülebilir. Akçay ve Özcebe (2012) tarafından yapılan bir çalışmada, bilgisayar oyunu oynama alışkanlıklarının okul öncesi dönem yaş grubuna kadar düştüğü ve özellikle 4-6 yaşta oyun oynama sürelerinin, bu yaş grubu çocukları için fazla olduğu belirlenmiştir. Yine, Gündoğdu ve arkadaşlarının (2016) araştırmalarında ise, çalışmanın örneklemini oluşturan her çocuğun en az bir ya da daha fazla teknolojik aletle, gün içinde 1 saat ya da 1 saatten fazla zaman geçirdikleri tespit edilmiştir. Erbay ve Durmuşoğlu Saltalı (2012) çocukların günlük yaşantılarında yaptıkları rutin etkinliklerde oyunun yerini araştırdıkları çalışmalarında çocukların sanatsal etkinlik yapma, ev işlerine yardım etme, bilgisayarla zaman geçirme ve gezmeye gitmelerinin yanında hemen hemen tamamının en fazla oyun oynadığı ve yine büyük bir çoğunluğunun televizyon izlediği sonucu ortaya çıkmıştır. Çalışmada oyun oynama ile televizyon izleme durumlarının birbirinin yerini almaları endişesi özellikle dile getirilmiştir.

Çalışmanın verilerinden yola çıkılarak ailelere, çocukların akranları ile birlikte sosyal oyunlar oynamalarını teşvik etmeleri, açık alan oyunlarına önem vermeleri, firsat yaratmaları ve teknolojik oyunlarla geçirdikleri zamanın kısıtlanması gerektiği söylenebilir. Bu kapsamda, ebeveynlerin ya da aile büyüklerinin kendi çocukluklarında oynadıkları oyunları çocuklara öğretmeleri, onlarla oynamak için firsat yaratmaları ve destek olmaları önemlidir. Ailece oynayabilecekleri oyunlar kurmaları ve böylelikle aile içi iletişimi güçlendirerek çocuğun sosyal beceriler kazanması desteklenmelidir. Ebeveynler çocukları ile birlikte artık malzemelerden oyuncaklar yapıp bu oyuncağı kullanarak oyunlar üretebilirler.

Öte yandan, okul öncesi eğitim kurumlarında oyun temelli etkinliklerin önemi de unutulmamalıdır. Bu doğrultuda öğretmenlere büyük görevler düşmektedir. Öğretmenlerin etkinliklerini oyun temelli yapılandırmaları, çocukları oyun kurma konusunda cesaretlendirmeleri ve çocukların oyunlarını planlamalarına yardımcı olmaları oldukça önemlidir. Öğretmenlerin oyun ve oyunun çocuk için önemi konusunda aileleri bilinçlendirmeleri, okul öncesi eğitimin amaçları konusunda bilgi vermeleri, aileleri çocukları için oyun ortamı kurma, birlikte oyun oynamaları için teşvik etmeleri ve birlikte oynanabilecekleri oyunlar önermeleri de yapılabilecekler arasında sayllabilir. 


\section{References}

Akçay, D., \& Özcebe, H. (2012). Okul öncesi eğitim alan çocukların ve ailelerinin bilgisayar oyunu oynama alışkanlıklarının değerlendirilmesi. Çocuk Dergisi, 12(2), 66-71. (Assessment of computer game habits of preschool children and their families. The Journal of the Child, 12(2), 66-71.)

Alat, Z., Akgümüş, Ö., \& Cavalı, D. (2012). Okul öncesi eğitimde açık hava etkinliklerine yönelik öğretmen görüş ve uygulamaları. Mersin Üniversitesi Eğitim Fakültesi Dergisi, 8(3), 47-62. (Teacher views and practices on outdoor activities in pre-school education. Mersin University Journal of the Faculty of Education 8(3), 47-62.)

Başal, H. A. (2007). Geçmiş yıllarda Türkiye'de çocuklar tarafından oynanan çocuk oyunları. Uludă̆ Üniversitesi Eğitim Fakültesi Dergisi, 20(2), 243-266. (Child games played in Turkey by children during the past years, Journal of Uludag University Faculty of Education, 20(2), 243-266).

Bodrova, E., \& Leong, D. (2003) Chopsticks and Counting Chips: do play and foundational skills need to compete for the teacher's attention in an early childhood classroom? Young Children, 58(3), pp. 10-17.

Cevher-Kalburan, N. (2014). Okul öncesi dönem çocuklarının dış mekanda oyun firsatları ve ebeveyn görüşleri. Sosyal Politika Çalışmaları Dergisi, 32, 113-135. (Preschool children's opportunities and parents' opinions regarding outdoor play, Journal of Social Policy Studies, 32, 113-135).

Clements, R. (2004). An investigation of the status of outdoor play. Contemporary Issues in Early Childhood, 5(1). 68-80.

Çelik, A. (2012). Okul öncesi eğitim kurumlarında açık alan kullanımı: Kocaeli Örneği. Atatürk Üniversitesi Ziraat Fakültesi Dergisi, 43(1), 79-88. (The use of open space in the preschool education institütions: Kocaeli sample, Journal of the Faculty of Agriculture,43(1), 79-88).

Dale, D., Corbin, C. \& Dale, K. (2000) Restricting Opportunities to be Active during School Time: do children compensate by increasing physical activity levels after school? Research Quarterly for Exercise and Sport, 71(3), 240-48.

Deretarla-Gül, E. (2012). Ailelerin çocuk bahçelerine ve çocuk bahçelerindeki materyallere bakış açılarının incelenmesi. Çukurova Üniversitesi Sosyal Bilimler Enstitüsü Dergisi, 21(3), 261-274. (Examination of the views of the parents on the children's gardens and the materials in the children's gardens, Journal of Çukurova University Institute of Social Sciences, 21(3), 261-274).

Durualp, E., \& Aral, N. (2010). Altı yaşındaki çocukların sosyal becerilerine oyun temelli sosyal beceri eğitiminin etkisinin incelenmesi. Hacettepe Üniversitesi Ĕgitim Fakültesi Dergisi, 39, 160-172. (A study on the effects of play-based social skills trainıng on social skills of six-year-old children, H.U. Journal of Education, 39, 160172).

Erbay, F. ve Durmuşoğlu Saltalı, N. (2012). Altı yaş çocuklarının günlük yaşantılarında oyunun yeri ve annelerin oyun algısı. Ahi Evran Üniversitesi Kırşehir Eğitim Fakültesi Dergisi, 13(2), 249-264. (The place of play in six-year-olds' daily life and mothers' play perception. Ahi Evran University Journal of Kırşehir Education Faculty (JKEF), 13(2), 249-264).

Fleer, M (2014). Theorising Play in the Early Years. New York: Cambridge Unv Press.

Fleer, M (2013). Play in the Early Years . New York: Cambridge Unv Press.

Fleer, M. (2010). Early Learning and Development:Cultural-Historical Conceps In Play. Melbourne : Cambridge Unv Press.

Given, L. M., Davidson, C., Danby, S., Thorpe, K., Winkler, D. C., \& Wilson, R. (2015). Documenting young children's technology use: Observations in the home. Proceedings of the American Society for Information Science and Technology, 5l(1), 1-9.

Gönen, M., \& Saranlı, A. G. (2014). Okul öncesinde kapalı ve açık hareket alanlarının yeterliliğinin değerlendirilmesi: Başkent Ankara Örneği. Eğitim ve Öğretim Araşttrmaları Dergisi, 3(3), 409-419. (Evaluation of the adequacy of indoor and outdoor movement spaces in early childhood settings: case of capital city Ankara. Journal of Research in Education and Teaching, 3(3), 409-419). 
Gözalan, E., \& Koçak, N. (2014). Oyun temelli dikkat eğitim programının 5-6 yaş çocukların kelime bilgi düzeylerine etkisinin incelenmesi. KMÜ Sosyal ve Ekonomik Araştırmalar Dergisi, 16(2), 115-121. (The effect of game-based training program on the 5-6 aged childrens vocabulary. Journal of Social and Economic Research, 16(2), 115-121).

Gündoğdu, Z., Seytepe, Ö., Pelit, B. M., Doğru, H., Güner, B., Arıkız, E., Akçomak, Z., Kale, B., Moran, İ., Aydoğdu, G., \& Kaya, E. (2016). Okul öncesi çocuklarda medya kullanımı. Kocaeli Üniversitesi Sağllk Bilimleri Dergisi, 2(2), 6-10. (Media use by preschool-aged children. Journal of Health Sciences of Kocaeli University, 2(2), 6-10).

Hirsh-Pasek, K., Golinkoff, R. M., Berk, L. E., \& Singer, D. G. (2009). A mandate for playful learning in preschool. Oxford University Press.

Jones, E., \& Cooper, R. M. (2006). Playing to get smart. Teachers College Press.

Kaya, A. (2010). Oyun müdahale programının 3-5 yaş arasındaki özel gereksinimli çocukların bilişsel becerilerinin desteklenmesindeki etkililiğinin incelenmesi. (Yayınlanmamış yüksek lisans tezi). Ankara Üniversitesi, Ankara. (The effectiveness of play intervention program (PIP) on the cognitive skills of children with special needs with range of 3-5 years (Unpublished master thesis). Ankara University, Ankara).

Kerkez, F., (2002). Çocuklarını anaokuluna gönderen ailelerin oyun ve spora yönelik tutumları (Trabzon Örneği). Marmara Üniversitesi Spor Araştırmalar Dergisi, 6(16). Attitudes of families of preschool children towards game and sports (Trabzon Sample). Marmara University Journal of Sport Research, 6(16).

Koçan, N. (2012). Çocuk oyun alanlarının yeterliliği üzerine bir araştırma: Uşak Kenti Kemal Öz Mahallesi Örneği. Erciyes Üniversitesi Fen Bilimleri Enstitüsü Dergisi, 28(4), 315-321. (A study on the competence of children's playgrounds: an example of Uşak city Kemaloz district. Erciyes University Journal of the Institute of Science and Technology, 28(4), 315-321).

Koçyiğit, S., \& Baydilek-Başara, N. (2015). Okul öncesi dönem çocuklarının oyun algılarının incelenmesi. Yüzüncü Yll Üniversitesi Eğitim Fakültesi Dergisi, 12(1), 1-28. (Analysis of the preschool children's perceptions about play. Journal of Education Faculty, 12(1), 1-28).

Kudaş, S., Ülkar, B., Erdoğan, A., \& Çırçı, E. (2005). Ankara ili 11-12 yaş grubu çocukların fiziksel aktivite ve bazı beslenme alışkanlıkları. Hacettepe Spor Bilimleri Dergisi, 16(1), 19-29. (Physical activity and some eating habits of 11-12 year old children in Ankara province. Hacettepe Journal of Sport Science, 16(1), 19-29).

Kuru, O., \& Köksalan, B. (2012). 9 yaş çocuklarının psiko-motor gelişimlerinde oyunun etkisi. Cumhuriyet International Journal of Education, 1(2), 37-51. (The influence of the games on the psychomotor development of the children at the age of nine. Cumhuriyet International Journal of Education, 1(2), 37-51).

Metin-Aslan, Ö. (2013). Anaokuluna devam eden çocukların oyun davranışları ve oyunlarında ortaya çıkan zorbalık davranışlarının incelenmesi. (Yayımlanmamış doktora tezi). Hacettepe Üniversitesi, Ankara. (Analyzing preschool children's bullying and play behavior during play (Unpublished doctorate thesis). Hacettepe University, Ankara)

Miller, E. \& Almon, J. (2009). Crisis in the kindergarten: Why children need to play in school. College Park: Alliance for Childhood.

Nicolopoulou, A. (2010). The alarming disappearance of play from early childhood education. Human Development, 531, 1-4.

Pica, R. (2003) Your Active Child: how to boost physical, emotional, and cognitive development through ageappropriate activity. Chicago: Contemporary Books.

Şener, S. M. (2001). İlköğretim okullarında açık alan performansının değerlendirilmesi ve okul oyun alanları için tasarım kriterleri. (Yayınlanmamış yüksek lisans tezi). İstanbul Teknik Üniversitesi, İstanbul. (Evaluation of primary schools' open space performance and design principles for schoolyards (Unpublished master thesis). Istanbul Technical University, Istanbul). 
Taylı, A. (2007). Kardeş sahibi olup olmama durumunun okul öncesi dönemdeki sosyal oyuna etkisi. Abant İzzet Baysal Eğitim Fakültesi Dergisi, 7(1), 103-115. (The effects of having siblings or being a singleton child of social play in preschool age children. Abant İzet Baysal University Journal of Faculty of Education, 7(1), 103115).

Tedmem (2016). Anaokulları ilkokul birinci sınıflara $m \imath$ dönüştü?. https://tedmem.org/memnotlari/degerlendirme/anaokullari-ilkokul-birinci-siniflara-mi-donustu adresinden 24.10 .2017 tarihinde edinilmiştir.

Toran, M., \& Dilek, A. (2017). Çocuklar ve kitaplar: Piaget'in oyun kuramına göre bir değerlendirme. Yaşadıkça Eğitim, 31(1), 41-54. (Children and books: an assessment based on Piaget's play theory, Journal of Education for Life, 31(1), 41-54).

Türkiye Beslenme ve Sağlık Araştırması. (2010). Beslenme durumu ve alışkanlıklarının değerlendirilmesi sonuç raporu. Ankara: T.C. Sağlı Bakanlığı Yayınları. http://www.sagem.gov.tr/TBSA Beslenme Yayini.pdf adresinden 24.10.2017 tarihinde edinilmiştir.

Türkoğlu, B., \& Uslu, M. (2016). Oyun temelli bilişsel gelişim programının 60-72 aylık çocukların bilişsel gelişimine etkisi. Uluslararası Ĕgitim Bilimleri Dergisi, 3(6), 50-68. (The effect of game based cognitive development programme on cognitive development of 60-72 months old children. The Journal of International Education Science 3(6), 50-68).

Veitch, J., Bagley, S., Ball K., \& Salmon, J. (2006). Where do children usually play? A qualitative study of parents' perceptions of influences on children's active free-play. Health\&Place, 12, 383-393. 